\title{
Del ensayo y el poema en prosa a la narración en Ensayos y poemas de Julio Torri
}

\author{
From the essay and the poem in prose to the narration \\ in Ensayos y poemas by Julio Torri
}

\author{
Adriana AzUCEna RodríGuez \\ Universidad Autónoma de la Ciudad de México \\ azucena.rodriguez@uacm.edu.mx
}

RESUMEN: Este artículo se ocupa de establecer las dos vertientes genéricas que determinan los textos de Ensayos y poemas, publicado por Julio Torri en 1917. El artículo incluye la revisión de los testimonios del autor en el establecimiento del género. Se propone una serie de características que permiten analizar los

\author{
Palabras clave: \\ Torri; \\ ensayo; \\ poema; \\ minificción; \\ género.
}

KEYWORDS:

Torri;

Essay;

Poem;

Micro-fiction;

Genre.
ABSTRACT: This article deals with establishing the two generic aspects that determine the texts of Ensayos y poemas, published by Julio Torri in 1917. The article includes the review of the author's testimonies in the establishment of his selected genre. It proposes a series of characteristics that allow us to analyze the essays and prose poems that make up this volume. From this characterization, it is contrasted with the features of the so-called micro-fiction or sudden fiction, an emerging genre that, in the concern to fix a tradition and a series of textual models, has established this work as inaugural. 
Para 1917, Julio Torri tiene 28 años, ya ha visto marchar a sus amigos más cercanos, maestros y condiscípulos ateneístas, ya ha recibido todo tipo de elogios públicos en revistas y diarios en México y Europa, y por fin, publica Ensayos y poemas, en la Editorial Porrúa. Por aquella segunda década del siglo, el ensayo y la narrativa se renuevan con obras fundamentales: Horacio Quiroga, también en 1917, publica Cuentos de amor, de locura y muerte; un año antes, Ramón López Velarde, La sangre devota; en 1915, Mariano Azuela publicaba por entregas Los de abajo. Alfonso Reyes publicaba también su ensayo nacionalista Visión de Anáhuac, texto fundador de la identidad mexicana. Al observar esta serie de obras, nada parecería anunciar lo que representaría, en el ámbito narrativo, el breve conjunto de textos reunidos en este libro; si bien se consolidaba la tradición del poema en prosa y el ensayo en México, ${ }^{1}$ el de Torri era un proyecto distinto, capaz de sugerir lecturas que escapaban a lo imaginado por su autor.

Ensayos y poemas es un título escueto, adecuado para este conjunto de 21 textos breves: un título tan descriptivo como ambiguo. Incluidos en antologías de cuento, de poema en prosa y ensayo, pero excluidos de la tradición canónica del ensayo nacionalista, dichos textos corresponden a una modalidad de escritura destinada a la marginalidad por su brevedad, pero, sobre todo, por su ligereza temática. Julio Torri optó por un género de difícil acceso para la crítica: esa particularidad de la prosa en su forma breve, ya sea lírica o ensayística, de propósito didáctico e interpretativo, tono personal y subjetivo, hibridación genérica y diversidad temática - características que pueden aplicarse por igual a las líneas del ensayo y el poema-. El autor tiene una idea precisa del género al que respondería cada texto; así, en su carta del 23 de agosto de 1916 comunica a Pedro

1 Luis Ignacio Helguera, en el estudio preliminar a su Antología del poema en prosa en México observa: "Los orígenes de la nueva forma literaria en México habría que rastrearlos no sólo ni principalmente en la fuerte influencia de la literatura francesa y, de manera más general, en el afrancesamiento de la sociedad y la sensibilidad mexicanas, sino en la filtración de esa literatura a través del modernismo sudamericano, en que la poesía en prosa surgía como una alternativa en la búsqueda de renovación expresiva: la profunda huella de Darío en Amado Nervo, las versiones de Baudelaire, Mendès y otros poetas franceses realizadas por Del Casal y el propio Darío que Ilegaron hasta nuestro país" (17), para incorporar a su antología a por lo menos veinte autores de poema en prosa modernistas o ateneístas. 
Henríquez Ureña los lineamientos de su próximo proyecto: “Pienso publicar un libro el año que viene, cuando reúna cinco, por lo menos, ensayos como Beati qui perdunt y En elogio del espíritu de contradicción, y veinte o veinticinco poemas en prosa y ensayos cortos, a manera de Del epígrafe y de A Circe" (Torri 1995: 246).

En efecto, parte de la obra responde a la expresión "poemas en prosa", creada por Baudelaire "para referirse a una modalidad de expresión literaria en la que se elabora una prosa que, libre de las exigencias del metro y de la rima, comporta un grado tal de musicalidad y de belleza artística como para poder adaptarse a 'la expresión de los mandamientos líricos del espíritu, a la ondulaciones del ensueño y a los sobresaltos de la conciencia'" (Estébanez: 850). Otra parte de la obra muestra las características del ensayo: "escrito en prosa, generalmente breve, de carácter didáctico e interpretativo, en que el ensayista aborda, desde un punto de vista personal y subjetivo, temas diversos, con gran flexibilidad de métodos y clara voluntad de estilo" (Estébanez: 326). Sin embargo, la crítica incorpora al autor, tempranamente, a las antologías de cuento. Como anota Dolores Koch - autora de uno de los textos fundacionales del estudio de lo que Ilama, como teórica, micro relato-, en 1926 Bernardo Ortiz de MonteIlano incluye a Torri en su Antología de cuentos mexicanos, publicada por Saturnino Calleja (Koch: 27).

Analizar las técnicas genéricas del ensayo y el poema en prosa, para dilucidar los elementos narrativos que los sitúan como base de la minificción, es el propósito de estas páginas. Las características de ambos géneros confluyeron en la genealogía de lo que se consideraría un género distinto a los anteriores.

\section{La argumentación como pauta creativa en Ensayos y poemas}

Al margen de tal discusión, la noción de género proporciona mecanismos para descubrir los procedimientos estilísticos de un autor. La elección del ensayo, en este volumen, delata una relación de éste con la poesía. Según el diccionario, la diferencia específica del ensayo frente a otros géneros radica en su carácter didáctico para tratar un tema con un propósito per- 
suasivo. La condición se cumple en textos desde cuyos títulos se anuncia, mediante el deíctico, tratamiento de un asunto: "De una benéfica institución", "De funerales", "De la noble esterilidad de los genios". Predominan las definiciones y afirmaciones acerca de asuntos subjetivos como la creación. Ahora bien, para el análisis textual —que pretende señalar los vínculos entre géneros-, las definiciones de ensayo suelen resultar un tanto abstractas, aunque profundamente reveladoras, como la acuñada por uno de sus autores fundamentales, Georg Lukács:

hay muchos escritos nacidos de sentimientos semejantes [temperamentos humanos] que no entran en contacto con la literatura ni con el arte, escritos en los que se plantean las mismas cuestiones vitales que en los que se llaman crítica, sólo que directamente enderezadas a la vida; no necesitan la mediación de la literatura y el arte. De este tipo son precisamente los escritos de los más grandes ensayistas: los diálogos de Platón y los escritos de los místicos, los ensayos de Montaigne y las imaginarias páginas de diario y narraciones de Kierkegaard (Lukács: 95).

En cuanto a las características del género, conviene partir de las establecidas por José Luis Gómez-Martínez — citado en el Diccionario de términos literarios:

1. Brevedad: el ensayista no pretende ser exhaustivo en el tratamiento de los temas, [...] su función "es sólo abrir nuevos caminos e incitar a su continuación". 2. Carácter sugeridor e interpretativo: el ensayista no es un creador, ni un investigador o especialista en la materia; "el valor del ensayo no depende del número de datos que aporte, sino del poder de las intuiciones que se vislumbren y de las sugerencias capaces de despertar en el lector (ello explica el hecho de la imprecisión en las citas)" [...] 3. Carácter confesional: el ensayo está lleno de apreciaciones subjetivas, a través de las cuales el autor comunica su propia visión del mundo, sus impresiones y sentimientos surgidos al contacto con la realidad [...] 4. Intención dialogal: el ensayista pretende comunicarse con sus lectores [...] 5. Carencia de una estructura prefijada: el ensayo, al contrario del tratado científico, del discurso o del estudio monográfico, no tiene un orden lógico y sistemático (aunque tenga orden interno y coherencia), sino que la comunicación progresa por medio de asociaciones y de intuiciones [...] 6. Variedad temática: que explica, a su vez, los diferentes tipos de ensayo: histórico, político, sociológico, autobiográfico, literario, etc. [...] 7. Voluntad de estilo: 
[...] El ensayista es consciente de que se espera de él una calidad estética en la expresión de sus ideas (Estébanez: 327-328).

La necesidad de una generalización, como es posible observar, trae como consecuencia la ambigüedad, pero ya señala pautas evidentes en el libro de Torri: la brevedad —aunque este rasgo permite unos criterios de medición tan laxos como convenga al ensayista-, el "carácter confesional" y la "intención dialogal", visible en inicios con frases para atraer la atención de un púbico: "Confieso que el espíritu de contradicción no me irrita al punto y medida que al común de los hombres..." (Torri 2011: 106108), o "Permitidme que dé rienda suelta a la antipatía..." (2011: 127). Esos rasgos delatan la pertenencia al género ensayístico y lo distancian de la lírica y de la narrativa. Otros rasgos corresponden al contenido temático como la ausencia de orden lógico y la variedad de asuntos. Mientras que los otros rasgos se refieren al efecto. El mismo Julio Torri, en "El ensayo corto", reflexiona acerca del género y coincide con el planteamiento genérico de Aullón de Haro. Por principio, el rechazo al tratamiento exhaustivo del tema, pues "nada más lejos de las formas puras del arte que el anhelo inmoderado de perfección lógica" (118). Asimismo, hace evidente la pretensión de brevedad y de la asociación de ideas e intuiciones como eje de la disertación ensayística: "Su carácter propio procede del don de evocación que comparte con las cosas esbozadas y sin desarrollo. Mientras menos acentuada sea la pauta que se impone a la corriente loca de nuestros pensamientos, más rica y de más vivos colores será la visión que urdan nuestras facultades imaginativas" (118). Y su propósito de asombro más que de formación del público: "Prefiero los saltos audaces y las cabriolas que enloquecen de contento, en los circos, al ingenuo público del domingo" (118).

Sobre la estructura verbal del ensayo, en consecuencia, es difícil fijar procedimientos. Aullón de Haro ha señalado la cercanía discursiva del ensayo a la argumentación, aunque advierte sus diferencias con respecto a la argumentación "dura": "un tipo de discurso vinculable, por la explicitud del razonamiento, al discurso de la argumentación; sin embargo [el ensayo] no se atiene a las elaboraciones lógicas de lo argumentativo, a la sistemática del entimema, del silogismo, de los métodos demostrati- 
vos o de prueba. Quiere decirse, pues, que el discurso del Ensayo, y por consiguiente el género mismo, constituye una categoría aún no definida" (Aullón 1992: 128).

El discurso argumentativo, entonces, ofrece una serie de pautas para contrastar aspectos verbales y la función de este discurso en la construcción del texto ensayístico de Julio Torri. La crítica se ha centrado en la prosa lírica y en sus aportaciones al relato breve o minificción, pero no se han contemplado a profundidad los aspectos ensayísticos que estructuran al menos la mitad del libro y responden a la intención del autor - aspectos que, parcial y posteriormente, fueron adoptados por los géneros breves-. Algunos elementos de este tipo de discurso intervienen en la construcción de aspectos determinantes de Ensayos y poemas, como la ironía, la precisión verbal o el manejo de la anécdota.

Por principio, uno de los rasgos discursivos del ensayo es el uso del presente. Aullón de Haro establece que el discurso del ensayo "es sustancialmente un discurso imperfectivo, del tiempo presente, y por eso es relacionable lingüísticamente con el discurso descriptivo, pero no sería asimilable ni a la descripción científica ni a la descripción artística" (1992: 128). En tanto que Liliana Weinberg muestra que este rasgo del ensayo es un desafío impuesto por la misma esencia del género: "El tiempo presente del ensayo no es sólo el propio de la explicación [...], sino también el presente de la enunciación de un proceso inacabado, del que se da cuenta precisamente en el momento de su realización e inscripción" (Weinberg: 50). Este uso del presente se encuentra en casi todos los textos de Ensayos y poemas y en la generalidad de la obra de Torri: se declara en "El maestro" que "con el crear, es el enseñar la actividad intelectual superior. Se trata, seguramente, de una forma más humilde que la otra" (Torri 2011: 100) y se usa el presente para evidenciar el propósito de definir. También se usa para marcar acciones habituales o definiciones; aparece en frases como "el epígrafe se refiere pocas veces de manera clara y directa al texto que exorna" (2011: 102). Otros usos de este modo verbal incluyen el presente histórico en "La vida del campo": "Va el cortejo fúnebre por la calle abajo" (105) y, por último, en "El raptor", el presente del modo imperativo: "Amigos míos, ayudadme a robar una novia que tengo en Real de Pozos" (127), texto que tiene las características del exhorto que busca persuadir a 
su auditorio para realizar una acción: "Por eso os pido ayuda, que si ella tuviera voluntad en seguirme... [...] Ayudadme, mis amigos. Tened compasión de un hombre enamorado, y mañana haced de mí lo que gustéis" (127). ${ }^{2}$

Las ideas del ensayo se encuentran entre la argumentación y la demostración. Chaïm Perelman observó las relaciones entre la lógica y la retórica en la formación de enunciados para defender una tesis con razones convincentes que la vuelvan probable o susceptible de ser aceptada como verosímil (cfr. Perelman: 18). Este planteamiento corresponde a la primera mitad del siglo pasado, pero se basa en la ensayística antigua y moderna. En esta disciplina, Anthony Weston sintetiza estrategias para estructurar argumentos cortos, en modelos básicos de argumentación, como el ejemplo. La cercanía de los textos de Ensayos y poemas con la narrativa se debe, entre otras causas, a la recurrencia del autor en el uso de los llamados "argumentos mediante ejemplos": un hecho que se toma como modelo, positivo o negativo, para ser seguido, rechazado o para respaldar una opinión - el origen de la narrativa breve se encuentra en ese recurso-. En argumentación, los ejemplos "ofrecen uno o más ejemplos específicos en apoyo de una generalización" (Weston: 33).

Torri inicia "De funerales" con un ejemplo particular: "Hoy asistí al entierro de un amigo mío. Me divertí poco, pues el panegirista estuvo muy torpe. Hasta parecía emocionado" (2011: 110). De ahí extrae su primera generalización que funciona como premisa: "Es inquietante el rumbo que Ileva la oratoria fúnebre", y propone un ejemplo más general: "En nuestros días se adereza un panegírico con lugares comunes sobre la muerte y ¡cosa increíble y absurda! Con alabanzas para el difunto" (110). Los ejemplos son, sin embargo, carentes de verificación y, además, claramente irónicos: es natural que un entierro no sea divertido y que se alabe al difunto. La condición de los argumentos mediante ejemplos es que sean ciertos o la premisa no será fiable. A partir de ambas condiciones, la conclusión

2 "El raptor" sería una arenga, es decir, un discurso que forma parte de la oratoria, para incitar a los receptores a seguir al orador: por eso el discurso del raptor incluye promesas de futuros pagos, victimización del hablante por el amor y rechazo de la joven a la que pretende raptar o preguntas retóricas: “¿Por qué vaciláis? ¿Para cuándo son los amigos?" 
de Torri resulta ambigua, igualmente irónica: "Y mientras las gentes no acepten estas ideas, continuaremos yendo a los entierros con tan pocas probabilidades de divertirnos como a un teatro" (110).

El argumento de autoridad es un modo de persuasión basado en el señalamiento de que personas prominentes opinan como el que argumenta, proporciona información que no estaría al alcance del autor de otro modo. Además, aludir a una autoridad asegura la fiabilidad de la premisa. Evidentemente, la cultura libresca de Julio Torri lo lleva continuamente a este tipo de argumento, descrito por Weston con la fórmula: " $X$ (alguna fuente que debe saberlo) dice que Y. Por lo tanto, Y es verdad" (55). Julio Torri, en "El maestro" plantea la premisa "Crear y enseñar son actividades en cierto sentido antitéticas". Y la comprueba mediante la autoridad: "La parábola de Wilde, del varón que perdió el conocimiento de Dios y obtuvo en cambio el amor de Dios tiene una exacta aplicación en arte" (2011: 102). Lo dicho por la autoridad, sin embargo, requiere interpretación: el artista al perder el conocimiento de Dios, obtiene a cambio su amor pues se convierte en maestro, servidor de sus semejantes. La interpretación de la parábola da la pauta para la conclusión-demostración de la premisa: "En cambio de las voces que no recogió, ofrecerá a la especie un rudo sacrificio: la mariposa divina perderá sus alas y el artista se tornará maestro de jóvenes" (102).

Otro tipo visible de los argumentos en Ensayos y poemas corresponden a la correlación o relación entre eventos. Según Weston, se acerca a los "argumentos acerca de las causas", es decir, la correlación se explica por una relación de causalidad "entre dos acontecimientos o tipos de acontecimientos [...] Cuando pensamos que $A$ causa $B$, usualmente pensamos no sólo que $A$ y $B$ están correlacionados, sino también que tiene sentido para A causar B" (Weston: 67). El segundo enunciado de "En elogio del espíritu de contradicción" ofrece una correlación de acontecimientos que parecen tener sentido causal: "Si una persona nos contradice siempre es porque existe en ella una oculta aversión hacia nosotros" (Torri 2011: 106). La relación no es, necesariamente, causal, pero el ensayista establece ese sentido.

Otro caso de argumentación es el de analogía. Un asunto similar que se relaciona con otro por semejanzas que deben ser mostradas, como el establecimiento de semejanzas entre el campo y el cementerio en "La vida del campo": 
-También amanece en los cementerios, y desde las musgosas tapias cantan los pinzones.

- ¿Y los amigos que abandonas?

- En los camposantos se adquieren buenos camaradas. En la pertinaz Ilovizna de diciembre charlan agudamente los muertos (Torri 2011: 105).

Probablemente, es "Beati qui perdunt...!" el ensayo más complejo y extenso, el que reúne el mayor número de procedimientos estilísticos de Ensayos y poemas. Ya desde el título en latín, hay una dificultad, establecer la traducción: “¡Belleza que perdura!”. Se emplea el presente y comienza con una afirmación particularmente general: "Las cosas que vemos siempre afean nuestra vida" (2011: 111); categórica y polémica que se va demostrando con ideas de lo que, por el contrario, la embellecen. El espíritu, esencia de esa vida según el autor, se ve dañado por lo fijo, en oposición a la movilidad de viajar, de la "variedad infinita". El ensayista sigue con un enunciado que correlaciona la tendencia a la modificación, presente en el hombre, por desigualdad respecto al animal: "Renuncio a interpretar el instinto de conservación de los animales; pero en los hombres lo atribuyo a [la] curiosidad" (111).

La movilidad contra la permanencia apunta hacia la idea eje: el rechazo a la rutina, en contraposición a la de la natural tendencia a la movilidad —idea que no tiene relación directa con el título_-, apoyada por un argumento de analogía: la relación entre el interés en la vida y el interés que proporciona una novela: "Nos interesamos en el vivir como por el desarrollo de una novela" (111); con las aclaraciones que la hacen aceptable: "en la que el protagonista y el lector son una misma persona; [...] que leemos a veces de mala gana" (111). El lector, considerado en esta analogía también como "espectador", gustaría de los giros del personaje.

El ensayo contiene la diversidad temática característica del género y la ilación de ideas llega a resultar caótica en una primera lectura, como ya lo había hecho notar Pedro Henríquez Ureña en una carta dirigida a Torri el año anterior a la aparición del libro —el 10 de junio de 1916—: "Los tres primeros párrafos están, no sé por qué, mal relacionados entre sí: parecen aforismos" (en Torri 1995: 235). ${ }^{3}$ Otra analogía señala al personaje

3 El ensayo había aparecido en un número de La Nave, revista dirigida por Julio Torri. 
como esclavo del espectador, ansioso de modificaciones, y las necesidades básicas del individuo, que le exigen quietud. Esta idea se enlaza con la del individuo que lamenta una pérdida y el espectador que disfruta de presenciarla. Para el siguiente párrafo, el ensayista correlaciona la pérdida y la capacidad de las señoras para afrontarla como ocasión para las compras. Le sigue el párrafo "A veces apetecemos perder algún utensilio o prenda..." (Torri 2011: 112), sobre la admiración del ensayista a la humana "facultad de querer", en contradicción con las quejas por "carecer". El enunciado de cierre es aún más extraño al contexto: "¡Si los ladrones fueran más razonables y menos petulantes...!" (2011: 113). Se atisba cierto sentido entre el contenido y la conclusión, pero la correlación no es evidente, sino un ejercicio de interpretación.

El inicio del segundo de los tres apartados presenta la idea eje de la vida como obra de arte: "nuestra vida es una obra de arte que trabajamos incesantemente" (113). En esta labor, las pérdidas y su consecuente sufrimiento purifican, y construyen la grandeza trágica del héroe. Las mujeres poseerían este conocimiento, una cierta tendencia a la fatalidad. El apartado que cierra el ensayo es una disertación sobre la pérdida de amigos y la conclusión se refiere sólo a este último apartado: "Perder viejos amigos íntimos es un punzante dolor que dura siempre" (116).

Esta correlación de ideas, pragmática más que semántica, la inclusión de relatos a manera de ejemplos-argumentos y de argumentos de autoridad, son rasgos que coincidieron con el relato breve que halló en la obra de Torri un antecedente. La minificción adoptó modos alternativos de asociación de ideas o acontecimientos en función de la hiperbrevedad, relatos reducidos a su mínima extensión a fin de subrayar su función interpretativa. Así como sus alusiones a autores y obras en una normalización de la intertextualidad que ha llegado a considerarse uno de sus recursos más frecuentes.

\section{El poema en prosa}

Si se toman como rasgos característicos del poema en prosa, los espacios líricos, el uso de figuras retóricas, la presencia del "yo" en forma de confesión, meditación y otras formas de la interiorización, los textos que 
podrían considerarse, plenamente, poemas serían: "A Circe", "El mal actor de sus emociones", "La vida del campo", el texto sin título que inicia con "Caminaba por la calle silenciosa de arrabal...", "La balada de las hojas más altas", "Xenias", "Fantasías mexicanas", "El abuelo" y "Vieja estampa". Aunque también los ensayos llegan a presentar algunos de esos rasgos. Pedro Aullón también ha señalado la relación entre poema en prosa, fragmento y ensayo, en primer lugar, por su preocupación estética y, en segundo, "en virtud de las condiciones tanto de novedad como de brevedad que a todos ellos afecta" (2005: 22). Como se sabe, establecer las particularidades del poema en prosa es tan complejo como las del ensayo. Éstas se basan en la actitud de cada autor: en Baudelaire, predomina el elemento narrativo; mientras que Rimbaud favorece el fragmentarismo y la discontinuidad semántica y formal; Aloysius Bertrand se encuentra entre ambos polos y, así, la tradición del poema en prosa tendió hacia las posibilidades múltiples de lo lírico, lo prosaico y su hibridación (Utrera: 12). La observación de la realidad desde una visión subjetiva —es decir, la vinculación entre imágenes de la realidad externa y la irrealidad de las visiones interiores - configura la "iluminación" que buscaron, en diversos sentidos, los autores del poema en prosa. Otro rasgo reiterado por la crítica es el de la intensidad y concentración del poema. Y un tratamiento de los recursos expresivos característicos del lenguaje poético (recurrencias fónicas, paralelismo, metáforas, etc.) adaptados a la prosa. Con estos elementos, es posible analizar los textos con predominio lírico de Ensayos y poemas.

En algunos casos, los títulos denotan su pertenencia genérica, pues — como en "A Circe" o en "La balada de las hojas más altas" — hacen alusión a figuras vinculadas con el discurso amoroso, o de inspiración bucólica. En el segundo mencionado, los recursos poéticos se presentan desde el primer enunciado: "Nos mecemos suavemente en lo alto de los tilos de la carretera blanca" (Torri 2011: 120): una prosopopeya o personificación metafórica mediante la cual las hojas comunican lo que ven y perciben: "Nos mecemos levemente por sobre la caravana de los que parten y retornan" (2011: 120). Desde esa posición, la voz poética plural describe la humana en una serie de enumeraciones y paralelismos basados en la 
oposición:4 "Unos van riendo y festejando, otros caminan en silencio. Peregrinos y mercaderes, juglares y leprosos, judíos y hombres de guerra: pasan con presura y hasta nosotros llega a veces su canción" (120). Las hojas contrastan las miserias humanas con las imágenes bucólicas y una renovación del tópico beatus ille, pues se declaran dichosas de no pertenecer al ámbito humano. Este recurso conduce a otro: la écfrasis o descripción de lugares que, en la subjetivación poética, son visibles para ese "nosotras", en imágenes del paisaje cuya adjetivación presenta un marcado lirismo en epítetos de sentido metafórico que aluden a la armonía y en alusiones a la plástica del pintor simbolista Arnold Böcklin: "las matinales sinfonías en rosa y perla; del sedante añil del cielo, en el mediodía; de las tonalidades sorprendentes de las puestas del sol, cuando los lujuriosos carmesíes y los cinabrios opulentos se disuelven en cobaltos desvaídos y en el verde ultraterrestre en que se hastían los monstruos marinos de Böcklin" (120).

Esas imágenes no son visibles para ese individuo afanoso, cuyos problemas se acabarían con un "puñado de doblones o un milagro de Nuestra Señora de Rocamador. No son bellas sus desventuras". Así, la iluminación del poema se refiere a la belleza, inaccesible para el ser humano común.

Justo a la mitad de Ensayos y poemas, Torri incluye un texto sin título - "Caminaba por la calle silenciosa de arrabal, Ilena de frescos presentimientos de campo" (117)—, pero con un epígrafe de "Vagabundos" de Rimbaud, ${ }^{5}$ estableciendo así un vínculo con el poema en prosa. El de Torri alude a un estado solitario, onírico, característico de la lírica simbolista: "En un ambiente extraterrestre de madrugada polar, la cúpula de azulejos de Nuestra Señora del Olvido brillaba a la luna con serenidad extraña y misteriosa" (117). El motivo de la caminata favorece la exaltación de la autoconciencia y el poeta prolonga ese estado perceptivo del ambiente a lo

4 La integración de contrastes es un rasgo buscado por la poesía, como se evidencia en las figuras de oposición: oxímoron, antítesis y paradoja. Asimismo, el estructuralismo subrayó la oposición como uno de los rasgos característicos de la poesía.

5 "J'avais en effet, en toute sincerité d'esprit, pris l'engagement de le rendre a son état primitif de fils du soleil, et nous errions, nourris du vin des Palermes et fu biscuit de la route, moi pressé de trouver le lieu et la formule" [Yo había tomado, en efecto, y con toda sinceridad de espíritu, el compromiso de devolverlo a su estado primitivo de hijo del sol, y nosotros errábamos, alimentados con el vino de las Cavernas y el bizcocho de la ruta, yo, apurado por encontrar el lugar y la fórmula] (traducción mía). 
largo del segundo párrafo: "las flores parecían como alucinadas en el extrañísimo matiz de la Luna" (117). La "iluminación" viene posteriormente: una reflexión como conclusión del recuerdo, más que de la experiencia presente: “¿Por qué no me evadí entonces de la Realidad? ¡Hubiera sido tan fácil! ¡Ningún ojo sofisticado me acechaba!...” (117).

En un interés por vincular su obra lírica en prosa con una tradición sólida, el autor incursiona en un género ideal para su estética: la epigramática, de ironía mordaz y contundente: "Xenias" ${ }^{6}{ }^{6}$ La primera xenia se refiere a los trabajos del poeta "sin genio" que "ve correr el agua del río. En vano se fatiga por una nueva imagen poética sobre el correr del agua. La frase no viene nunca" (125). "El agua que pasa tiene una gran semejanza con su vida", contiene el tópico del río, con su enorme tradición simbólica: la vida como el río que pasa "también adelante sin dejarle versos en sus manos". La siguiente xenia, ahora dedicada al "hombre que escribía acerca de todas las cosas; nada en el universo escapó a su terrible pluma" (125), combina la enumeración y el paralelismo - "ni los rumbos de la rosa náutica y la vocación de los jóvenes, ni las edades del hombre y las estaciones del año" (125) - y concluye con el sarcasmo propio de los discursos epigramáticos: "Sin embargo, en sus funerales — que no fueron por cierto un brillante éxito social— nadie le comparó con Goethe. Hay además en su epitafio dos faltas de ortografía" (125). El uso de los recursos de la ironía y el sarcasmo reúne características del poema en prosa y la tradición latina.

En cuanto al poema más reconocido de Ensayos y poemas, "A Circe", se evidencian sus rasgos poéticos desde el inicio, con el tradicional apóstrofe a la diosa, reiterado en el segundo párrafo. Y presenta una de las imágenes más poéticas de la obra de Torri, lograda mediante la metáfora y el símil: "En medio del mar silencioso estaba la pradera fatal. Parecía un cargamento de violetas errante por las aguas" (99). El poema en prosa comparte con la lírica la recreación del instante presente, de ahí que ocupe con frecuencia ese tiempo verbal: "Mi destino es cruel". No obstante, el poeta que vuelve sobre los pasos del griego sabe que el material, la

6 Esta modalidad de poema de ocasión tiene su antecedente en Marco Valerio Marcial, autor de Xenia, en su libro XIII, "dísticos con motivo de la descripción de los presentes intercambiados durante las fiestas dedicadas al dios Saturno, en el mes de diciembre" (Lejavitzer: 2). 
anécdota original, está agotada — como ya lo intuía James Joyce mientras, por la misma época, preparaba una novela de más de 800 páginas sobre el mismo tema-; entonces, el escritor mexicano modifica el episodio y las consecuencias de ese episodio también se modifican. En este caso, con una resolución irónica, en el sentido de vuelco de fortuna: "Como iba dispuesto a perderme, las sirenas no cantaron para mí" (99); este revés presentado casi al final del texto es un recurso tanto de la poesía como de la prosa, pues "el uso del humor y la ironía son esenciales en la confrontación de códigos y en la subversión estilística que da al género una dimensión dialógica afín al discurso novelístico" (Utrera: 17).

Así, el texto lírico, con sus evidentes recursos poéticos, trasciende hacia el relato. Si consideramos que las características del relato son, como nos recuerda Alberto Paredes: 1. historia y trama; 2. acción, tema y motivo; 3. Discurso; 4. modos de narración y grado de realidad del relato, y 5 . los personajes (Paredes: 32-39), entonces podemos señalar, por contraste, un conjunto de textos abiertamente narrativos escritos por Julio Torri ${ }^{7}$ que, además, presentan el rasgo de usar una conjugación en pretérito. No todos cumplen con este rasgo, pero emplean una especie de presente histórico; en otros predomina el diálogo y la estampa: con esto, se fueron perfilando la hibridación, la intertextualidad y, en general, los recursos que se han venido consolidando en el microrrelato.

\section{Hacia el relato}

Tanto el poema en prosa como el ensayo contienen elementos que funcionan en el relato de diversos modos. El ejemplo, si bien no es un relato propiamente dicho, representa un caso concreto o una situación que ilustran la validez de la tesis; la lógica causal de los argumentos mantiene el mismo principio en el relato. En tanto que el poema en prosa, desde sus momentos iniciales, mostró, en algunos casos, posibilidades narrativas y

\footnotetext{
7 Javier Perucho considera Ensayos y poemas como un "auténtico -y espléndido- libro de microficciones, cuyas dos nítidas partes se distinguen por particulares elementos ficcionales o ensayísticos. La primera se nutre de los relatos 'Circe', 'El mal actor de sus emociones', 'La conquista de la luna', 'La vida del campo', 'Era un país pobre', 'Xenias', 'Fantasías mexicanas', 'El raptor', 'El abuelo' y 'Vieja estampa'" (56).
} 
cierta tendencia a la hibridación genérica, así como una búsqueda de lo que se llamó "iluminación" a partir de la intensidad, concentración y subjetivación de los fenómenos concretos. Estos rasgos renovaron no sólo el lenguaje poético, sino también el narrativo. En este sentido, Julio Torri incorporó a sus textos planteamientos sugerentes para la narrativa.

Ya sea en poemas en prosa o en ensayos, los protagonistas de estos textos son héroes fatuos que enfrentan situaciones reconocibles por la tradición que precede a Torri y que continuó en la formación de los modernistas y ateneístas: la propensión a la tentación o al virtuosismo estético, a los que sumó nuevos personajes de la modernidad. El humilde imitador de Odiseo que es rechazado por la perdición, el maestro incapacitado para la creación, el aprendiz que escala montañas para escuchar nada más que un consejo banal, los melancólicos terrestres después de la pérdida de la ilusión lunar, el muerto que descubre el cementerio como actualización del tópico beatus ille, el contradictor que se opone al principio de consecuencia, el raptor que necesita de la ayuda de sus allegados porque es incapaz de ganarse el amor de la futura raptada. A este grupo de figuras, Torri sumó situaciones para un personaje igualmente novedoso: el catálogo de escritores humildes, ya no el bohemio o el romántico, sino el poeta intrascendente, sin leyenda, que no alcanza la inmortalidad literaria, el escritor que no escribe, o el poeta sin genio y el escritor prolífico cuyo epitafio tiene una falta de ortografía. Los asuntos, pues, tanto de sus ensayos como de sus poemas suelen representar la preocupación banal que aquejaría al individuo letrado actual: la marginación, la vanidad, la inquietud solitaria ante la elección del epígrafe previo a la obra más bien humilde.

Lo curioso es que Torri eligió, justamente, el tipo de héroe y de conflicto que preferirá el siglo xx: el hombre sin atributos que emprende aventuras ridículas por banales y absurdas, o el héroe parodiado a quien el destino desprecia y niega la grandeza, estrategia — la intertextualidad basada en pasajes literarios claramente reconocibles- que convendrá al tipo de texto breve que conformarán, al menos en México, seguidores de la obra de Julio Torri: la minificción. Esos recursos del humor y la intertextualidad se instauraron en casi buena parte de los géneros narrativos, pero la característica de la brevedad apuntalaba Ensayos y poemas hacia el conjunto de textos que escritores, editores y teóricos Ilamarán minificción y, poste- 
riormente, recibirá otras denominaciones que describan la diversidad de textos breves en función de su propósito discursivo.

El origen del término se ubica en 1969, cuando Edmundo Valadés incluyó en la revista El Cuento la sección "Minificciones": textos muy breves, narrativos, originales e ingeniosos, de autores reconocidos o incipientes; estos últimos seleccionados mediante concursos permanentes. Otras revistas hispanoamericanas, durante los años ochenta, promovieron la publicación de textos señalados como "minicuento" o "cuento breve". Teóricos como Lauro Zavala (2006) han optado por el término "minificción"; Violeta Rojo (1997), "minicuento", y Dolores Koch (1986), "microrrelato". La crítica, establecida en sus particulares regiones, ha adoptado esas distintas nomenclaturas: en México y Colombia, por ejemplo, ha optado por "minificción", mientras que España y Argentina, por "microrrelato", convirtiéndose ambos términos en los más empleados. En el caso de esta investigación, se consideran sinónimos, aunque con la noción de microrrelato se pretende destacar el aspecto narrativo predominante de ciertos textos cuya principal característica es la brevedad. Para la publicación de Ensayos y poemas, el camino hacia la consolidación del microrrelato y la minificción era aún largo, si bien sus anuncios eran visibles, desde las pautas genéricas originalmente trazadas por el autor. Algunas de esas pautas propician la transición entre los géneros programados y las consecuencias de lectura orientadas hacia la percepción de los textos en tanto relato o minificción.

Ciertamente, Torri evadía la nominación de "cuento": optó por el título de Ensayos y poemas; cuando Carballo le pide que hable de sus libros, cuenta que "agrupo textos. [...] Cualquier idea, cualquier tema que se me ocurren, los apunto. De esa manera se llena uno de papeles" (en Carballo: 173); pero uno de sus grandes amigos y críticos contemporáneos, Alfonso Reyes, no duda en señalar que considera esos textos como cuentos: "El cuento, en manos de Torri, se hacía crítico y extravagante. Nunca ha publicado él sus páginas de entonces: el embustero que privaba de existencia a los que nombraba, el que se embriagaba con sangre de gallo, el descabezado que traía la cabeza pegada y no podía acercarse al fuego para que no se le derritiera el pegamento" (recuperado de Carballo: 173).

En respuesta al destino de esos textos, su autor evade mientras puede el término cuento, hasta que cede: "'El embuste', de carácter modernista, es 
un diálogo entre un hombre fuerte y un hombre débil: era una típica tomadura de pelo. En esa época leí los Contes cruels de Villiers de l'Isle-Adam. Allí encontré, tal vez, inspiración en esos textos. El cuento sobre el hombre que se embriagaba con sangre de gallo nunca lo escribí, se lo conté a Alfonso, quien olvida otro cuento de esos días: el del coleccionador de ataúdes" (en Carballo: 174).

La diferencia entre los relatos y los ensayos se encuentra, en buena medida, en la caracterización de los personajes: una ficción de ser humano, definido e individualizado, capaz de iniciar una acción y continuar sus consecuencias hasta que el autor considera el cierre del relato. Pongamos como contraste el primer texto de su segundo libro, el homónimo "De fusilamientos", fechado en 1915 aunque publicado en 1940: se menciona a un condiscípulo del ensayista, de los miembros del batallón, jefes y soldados rasos, que lleva a cabo el fusilamiento, las damas piadosas que suministran tabaco o aguardiente y el ambiguo fusilado, muchos o "uno". Como se puede observar, ninguna de las entidades puede considerarse un personaje; en cambio, es claramente visible que en "A Circe", la entidad comunicativa sintetiza las acciones realizadas: siguió las indicaciones de la diosa hacia la isla de las sirenas, evitó las medidas que frenaran su encuentro con ellas y, contrario a lo esperado, obtuvo el rechazo de las sirenas. Con esa sucesión de hechos, conforma el relato y, además, caracteriza psicológicamente al enunciador: obediente, con un propósito determinado, pesimista, desapegado y con un evidente sentido estético y subjetivo. La voz ya no es la del poeta o la del ensayista, sino un personaje con todos los requisitos de este elemento del relato.

Asimismo, el ambiente espacio-tiempo es fundamental para la construcción de la trama: la nave, recreada mediante la sinécdoque del mástil; la isla, con la comparación extraordinaria: "la pradera fatal. Parecía un cargamento de violetas errante", y el marco del mar, señalado con una sinécdoque humilde: "las aguas", el leitmotiv por excelencia de la aventura. Y el tiempo marcado por la sucesión cronológica de acciones.

Al comparar los fragmentos de "Xenias" (125), es visible la diferencia de modos discursivos que se encuentran en Ensayos y poemas: el primer fragmento emplea el tiempo presente - “El poeta sin genio ve correr las aguas del río"—; el segundo, el pretérito —- "Una vez hubo un hombre 
que escribía acerca de todas las cosas" - . El escritor atemporal del primer fragmento se inmoviliza ante un propósito casi mítico - "se fatiga por una nueva imagen poética sobre el correr del agua"—; mientras que el otro avanzó a través del conocimiento con el propósito de crearse un lugar en la posteridad — “Su vida giró alrededor de este pensamiento: 'Cuando muera se dirá que fui un genio, que pude escribir sobre todas las cosas...'"- El cierre del primer fragmento alude a una vida al margen de él — "su vida pasa también adelante sin dejarle versos en las manos"—; el desenlace en el segundo es un acontecimiento posterior a la biografía sintetizada — "Sin embargo en sus funerales [...] nadie le comparó con Goethe. Hay además en su epitafio dos faltas de ortografía". Ambos textos contienen tanto elementos del ensayo como del poema en prosa, pero en la relación con los límites tendientes a la reducción — cada vez más tolerados teórica, crítica y creativamente- del relato, se hace evidente un predominio de la narración en el segundo fragmento.

\section{Conclusiones}

Julio Torri parte de una concepción de ensayo relacionada con una tradición que incluye a Charles Lamb, Thomas de Quincey o Jonathan Swift: una ensayística marginal, antisolemne e irónica; a cambios de principios como la correlación de ideas, los modelos de argumentación que propician el diálogo entre pensadores del pasado y el presente, y recursos retóricos capaces de embellecer y oscurecer la expresión o los pasajes narrativos que sorprendieron a sus continuadores. Las anteriores notas respondieron a la preocupación inicial por atender la voluntad ensayística de Torri, que representa una guía de estudio que podría resultar eficaz, a pesar de la ambigüedad de los textos y su cercanía con posibilidades narrativas futuras.

El género literario, definido como "imperativos institucionales que se imponen al escritor y, a su vez, son impuestos por éste" (N. H. Pearson en Wellek y Warren: 271); en tanto que el autor crea una escuela como la que ahora se ha consolidado en la literatura mexicana e hispanoamericana. Si bien el género es una preocupación principalmente teórica, es también una entidad social, una comunidad que creadores y lectores llegan a pre- 
cisar; esto implica una serie de regulaciones basadas en los aspectos que intervienen en el proceso de lectura y su socialización. Los responsables de esta regulación son los diferentes grupos que conforman esta comunidad: escritores, editores y lectores. Como ha señalado Jorge Luis Borges, "cada escritor crea sus precursores. Su labor modifica nuestra concepción del pasado, como ha de modificar el futuro" (174). Julio Torri modificó, en efecto, el futuro de una narrativa que lo ha llevado, al margen tal vez de su intención, a ser considerado uno de sus precursores: la minificción.

\section{Bibliografía}

Aullón de Haro, Pedro. Teoría del ensayo. Madrid: Verbum, 1992.

Aullón de Haro, Pedro. "Teoría del poema en prosa", en Quimera, núm. 262 (octubre de 2005): 22-25.

Borges, Jorge LuIs. Otras inquisiciones. Buenos Aires: Emecé, 1996.

Carballo, Emmanuel. Protagonistas de la literatura mexicana. México: Secretaría de Educación Pública / Ediciones del Ermitaño, 1986.

Estébanez Calderón, Demetrio. Diccionario de términos literarios. Madrid: Alianza, 2001.

Helguera, Luis Ignacio (estudio preliminar, selección y notas). Antología del poema en prosa en México. México: Fondo de Cultura Económica, 1993.

$\mathrm{KOCH}$, Dolores. El micro-relato en México: Julio Torri, Juan José Arreola y Augusto Monterroso. Tesis. University of New York, 1986.

Lejavitzer Lapoujade. Amalia. "Introducción", en Hacia una génesis del epigrama en Marcial. Xenia y Apophoreta. México: Universidad Nacional Autónoma de México, 2000. 1-6.

LukÁcs, Georg. Esencia y forma del ensayo. Ed. Pedro Aullón de Haro. Madrid: Sequitur, 2015.

Paredes, Alberto. Las voces del relato. Madrid: Cátedra, 2015.

Perelman, Chaïm. "Logique formelle et logique informelle", en M. Meyer (ed.). De la métaphysique à la rhétorique. Bruxelles: Université de Bruxelles, 1986.

Perucho, Javier. Dinosaurios de papel. El cuento brevísimo en México. México: Ficticia, 2009.

Rojo, VioletA. Breve manual para reconocer minicuentos. México: Universidad Autónoma Metropolitana, 1997.

TORRI, JULIO. "Entrevista con Julio Torri. Prosas desconocidas de Julio Torri", en Diecinueve protagonistas de la literatura mexicana del siglo Xx. México: Empresas Editoriales, 1965. 139-151.

TORRI, JuLIO. Epistolarios. Edición de Serge I. Zaïtzeff. México: Universidad Nacional Autónoma de México, 1995.

TORRI, Julıo. "Ensayos y poemas", en Obra completa. Edición de Serge I. Zaïtzeff . México: Fondo de Cultura Económica, 2011. 97-129. 
Utrera Torremocha, María Victoria. Teoría del poema en prosa. Sevilla: Universidad de Sevilla, 1999.

Weinberg, Liliana. Pensar el ensayo. México: Siglo XXI, 2009.

Wellek, Rene y Austin Warren. Teoría literaria. Madrid: Gredos, 1985.

Weston, Anthony. Las claves de la argumentación. Barcelona: Ariel, 2006.

Zavala, LaURO. La minificción bajo el microscopio. México: Universidad Nacional Autónoma de México, 2006.

Adriana AZucena RodríGuez Torres

Licenciada en Lengua y Literatura Hispánicas (UNAM) y doctora en Literatura Hispánica por El Colegio de México. Profesora-investigadora en la Universidad Autónoma de la Ciudad de México y de la asignatura Teoría Literaria en la licenciatura en Lengua y Literaturas Hispánicas (FFYL- UNAM). Desde un enfoque teórico, ha realizado investigación de diversas áreas de la crítica y el análisis de textos: Siglos de Oro, Literatura mexicana contemporánea y géneros literarios emergentes (microficción). Autora de los libros Coincidencias para una historia de la narrativa mexicana escrita por mujeres (UNACH, 2016) y Las teorías literarias y el análisis de textos (UNAM, 2017), y de artículos como "La huella del cuento en Pedro Páramo", en Revista Fuentes Humanísticas, 55 (2017): 169-180. 